\title{
Hybride civilsamfundsorganisationer under forandring: neoliberale praksisser, marked og civile rettigheder
}

\author{
Linda Lundgaard Andersen
}

Frivillighed og civilsamfundet har spillet en vigtig rolle i transformationen af velfærdsstaten i Danmark. Civilsamfundet har traditionelt været påskønnet for et særligt bidrag til den lokale sammenhængskraft og for at skabe åbne, inkluderende og sociale fællesskaber. De seneste årtier har dog indvarslet en ny tid. Nu indgår civilsamfundet og frivillige (også) som strategiske samarbejdspartnere i løsninger af offentlige opgaver. I disse partnerskaber udvikles en særlig hybrid praksis, hvor det ulønnede og lønnede eksisterer side om side. I denne kronik belyser jeg, hvordan denne udvikling rummer både særlige styrker og særlige udfordringer for det frivillige sociale arbejde. Et forhold berører, hvordan civilsamfundsorganisationer (CSO'ere) nu skal virke under nye styrings- og organiseringsprincipper præget af New Public Management - i det jeg kalder de neoliberale praksisser. Et andet forhold berører, hvordan det ulønnede og lønnede arbejde og samvirke kan belyse en kritisk diskussion af, hvordan en social rettighedsposition nu udfordres af en entreprenøriel markedsdiskurs, hvor menneskelig vækst vareliggøres og tendentielt underlægges en performanceorienteret praksis.

\section{Civilsamfundet $\mathbf{i}$ transformation}

I de seneste årtier har vi set en betydelig forandring i de betingelser og rammer, der omgiver det civile samfund og de frivillige sociale organisationer. Tidligere var civilsamfundsorganisationerne (CSO'ere) primært orienteret mod autonome og selvstyrende aktiviteter og opgaver lokaliseret i lokalsamfund og forestod ofte parallelle eller komplementære aktiviteter til offentlige og lokale velfærdsindsatser. Det kunne for eksempel være væresteder for borgere i udsatte positioner, hjemløseindsatser, lektiecafeer og flygtningeindsatser, som på den ene side er velfærdsstatslige opgaver, men som på den anden side ikke kan skabe tilfredsstillende leve- og væresteder. Her tilbyder den frivillige sociale verden indsatser båret af andre logikker, som komplementære eller parallelle indsatser til offentlige velfærdsindsatser (Andersen, Larsen, Bisballe og Holm, 2008; Andersen, Nerup og Cauchi, 2007). I dag er flere CSO'er engageret i at levere civilt-baserede velfærdstjenester, som er en del af de offentlige velfærdsprofiler. Det kan for eksempel være i partnerskaber med kommuner, når de tilbyder indsatser til sårbare 
unge, til problemramte familier eller til unge mødre. Civilsamfundsforskere påpeger, hvordan civilsamfundsorganisationerne bygger broer på flere måder: mellem forskellige mennesker, forskellige ideologier og visioner og rækker også ud mod det bredere samfund. Det er en klassisk beskrivelse af civilsamfundsorganisationer med et socialt formål, at de virker gennem at give stemme til den gruppe af borgere, de virker i forhold til. For eksempel gennem 'advocacy'-aktivitet, hvor foreningerne kan blive talerør for hjemløse, unge i udsatte positioner eller unge mødre. CSO'erne har oftest en særlig dyb indsigt, som er båret frem gennem en bred vifte af værdier og idealer, som driver deres indsatser (Wijkström, 2011, s. 17). Derfor fremhæver flere forskere, hvordan civilsamfundets foreninger har en særlig evne til at fungere som motor for et aktivt medborgerskab, skabe aktivisme igennem sociale bevægelser og udvikle deltagelsesdemokrati (Boje, 2015, s. 40).

Civilsamfundet og grupper af frivillige indgår nu i højere grad end tidligere som del-elementer i offentlige indsatser, og deres aktiviteter og tilbud indgår i statslige og kommunale strategi-dokumenter. Gradvist er CSO'er blevet integreret som en del af en differentieret offentlig velfærdsservice-profil. Civilsamfundet og frivillige har historisk set haft en rolle i offentlige politikker og praksisser på grund af deres altruistiske, tætte og ligeværdige forhold til borgerne, der ofte har været baseret på et deltagelsesdemokrati. Civilsamfundsforskningen kan rapportere om de fordele, disse partnerskaber kan bidrage med: Når borgere, frivillige organisationer, velfærds-fagfolk og kommuner engagerer sig i samarbejder, oplever de synergi, merværdi og fælles styrkelse af mål og resultater. Når flere partnere bidrager forbedres mulighederne for mere innovative velfærdsløsninger. Derfor er der ofte forventninger til, at offentlige og civile partnerskaber kan producere fleksible løsninger på komplekse udfordringer ud- viklet tættere på borgernes behov og trivsel. Endelig har frivillig-kulturens traditioner og samarbejdsformer et potentiale til at udvikle flere hybride netværksorganisationer, hvor for eksempel frivillige, kommunale medarbejder og borgere kan udvikle velfærdsindsatser som bygger på lokalsamfundets ressourcer (Espersen, Andersen, Olsen, \& Tortzen, 2018; Andersen \& Espersen, 2017; Buckingham, 2011; Enjolras \& Strømsnes, 2017).

Denne udvikling har imidlertid også sine problemer. Det frivillige sociale arbejde er blevet mere og mere defineret og styret af markedsforhold (Fridberg og Henriksen, 2014; Eikenberry \& Kluver, 2004; Sandberg, 2016; Henriksen, 2015), er i højere grad end tidligere drevet af en offentlig-civil kontraktkultur og er begyndt at anvende en markedsretorik, der omskriver deres medlemmer, som nu kaldes serviceudbydere i steder for frivillige (Wijkström, 2010). Den offentlige kontraktkultur kan føre til isomorfi-processer, hvor forskellige civile og offentlige organisationer begynder at ligne hinanden. For at imødekomme forventningerne og leveranceaftaler gennemgår CSO'er et mission-skred, hvor deres formål langsomt undergår forandringer. Over tid kommer CSO'erne til at spejle den organisatoriske leveringskultur, struktur og kommunikation, som kendetegner deres samarbejdspartnere - for eksempel den kommunale og offentlige sektor. Denne udvikling sker ofte for at kunne styrke legitimitet og for at kunne tiltrække fondsstøtte og partnerskaber (Mason, 2012; Andersen, 2015b). Dette repræsenterer et væsentligt paradoks. CSO'er involveres ofte i offentlige partnerskaber, fordi de opererer uden regler og begrænsninger og er stærke i udvikling af netværk, samarbejde og social kapital. For at være attraktive partnere i det kommunale og politiske system og for at kunne tiltrække finansiering og støtte skal organisationer imidlertid udvikle samarbejder, der overholder regler og rutiner, der genereres af New Public Management 
(Espersen, Andersen, Olsen \& Tortzen, 2018). Dette kan i mange tilfælde være kontraproduktivt for det særegne i det frivillige sociale arbejde med rationaler og virkemåder, som er fremmed for civilsamfundskulturen (La Cour \& Højlund, 2008). Forskning peger imidlertid også på, hvordan civilsamfund og frivilligt socialt arbejde kan aktivere civil modstand på grund af, at frivillige aktive er forholdsvis selvstyrende og stærkt motiverede i deres involvering - og denne motivation er vanskelig at opretholde, hvis der er for store kontrol og rapporteringskrav. Så hvis kontrollen øges, vil frivillige simpelthen forlade deres engagement til fordel for andre aktiviteter, som rummer mindre grad af ekstern styring (Henriksen, Boje \& Ibsen, 2008; Boje, 2017).

\section{Civilsamfundsorganisationer: hybride sammenfletninger}

Civilsamfundsorganisationer befinder sig således i en forandringsproces. De er både selv skabere af menneskelig forandring via deres mange indsatser og aktiviteter, men de er også selv arenaer for forandring, fordi de indgår i en større samfundsmæssig forandring (Wijkström \& Zimmer, 2011, s. 10). Man kan tale om en "en forandring i arbejdsdeling" mellem civilsamfund og kommunale aktører, der fører til "en aendring i aktivitetsporteføljen" både for CSO'er men også for offentlige og private organisationer (Wijkström \& Zimmer, 2011, s. 12). Vi ser altså en særlig slags organisation, som kombinerer nonprofit og frivillighed med komponenter fra marked og salg. Der er derfor tale om en hybrid blanding af opgaver, rammebetingelser og økonomi. Hybride organisationer rummer både konkurrencedygtige fordele, men også udfordringer og vanskeligheder, der kan påvirke deres værdi, mission, forretning og organisation (Mair \& Noboa, 2003). De involverer flere interessenter, byder ind med mere differentierede mål og virker på baggrund af en blanding af ressourcer, der kombinerer offentlig finansiering, markedsindkomst og velgørenhed. Nogle forskere peger på, at denne kombination af markedsfordele og sociale formål giver fordele (Mair, Mayer \& Lutz, 2015; Billis, 2010; Brandsen, van de Donk \& Putters, 2005), mens andre påpeger at det rummer en potentiel svaghed, fordi det hybride kan påvirke eller ændre organisationsstruktur og virksomhedernes mission over tid (Evers, 2005; Pestoff, 2014; Billis, 2010; Buckingham, 2011).

Et konkret eksempel kan belyse disse fordele og dilemmaer for det frivillige ulønnede arbejde. Tre danske civilsamfundsorganisationer udviklede et fælles partnerskab for at kunne afgive et bud på en udlicitering af jobintegration til borgere uden for arbejdsmarkedet. De tre organisationer havde været ganske succesfulde i deres frivilligt og lokalt-baserede tilgang til at inkludere og inddrage borgere i marginaliserede positioner. Imidlertid medførte kommunale nedskæringer og gennemførelsen af en udliciteringspraksis for jobintegration, at byrådet formulerede særlige indkøbs- og udbudsbetingelserne. Hvis de tre civilsamfundsorganisationer skulle fortsætte deres aktiviteter - forankret i en civilsamfundsfilosofi - måtte de forsøge at tilrette deres indsatser. Deres tilgang kombinerede en behandlings- og aktivitetsprofil baseret på en stærk lighedsorienteret praksis, hvor borgere i aktiveringsforløb blev engageret i jobtræningsaktiviteter, hvor også en blandet gruppe af lokale borgere var aktive. Disse aktiviteter handlede om at styrke evnen til at kunne deltage i et socialt miljø, at blive i stand til fastholde arbejdsrelaterede aktiviteter og at kunne passe en brugttøjs-butik eller betjene en mobil kaffecykel-shop. Alle disse aktiviteter involverede forskellige former for professionelle færdigheder og kompetencer, som skulle tilegnes. Det frivillige sociale - og dermed ulønnede - arbejde bestod i, at borgere i jobtræning arbejdede side om side med lokale borgere, som 
deltog af egen lyst. Dette særlige fællesskab mellem det lønnede og det ulønnede bidrog til at skabe et unikt praksis-fællesskab, som virkede rehabiliterende. Konsortiet vandt udbuddet, og i de følgende år arbejdede de for at nå de mål og delmål detaljeret i udbuddet. Dette viste sig imidlertid at være vanskeligt. Det var vanskeligt at få økonomisk støtte til kombinationen af frivilligt ulønnet arbejde og lønnede jobintegrations-aktiviteter, idet jobintegrationspuljer kun støttede traditionel jobtræning - og ikke det ulønnede arbejde. Dermed var den ulønnede men uhyre væsentlige komponent i indsatsen ikke-finansieret. Samtidig krævede partnerskabets samarbejde med kommunale instanser mange møder, hvor resultater og målleverancer skulle afrapporteres og justeres med detaljerede tidsplaner og monitoreringsprocedurer, der var tidskrævende. På sigt viste det sig, at det nye partnerskab langsomt ændrede den behandlingsfilosofi som CSO'erne oprindeligt hvilede på og dette førte til en reduktion af deres resultater.

\section{Neoliberale praksisser}

Vi kan forstå disse udviklinger som neoliberale praksisser. Neoliberalisme er ifølge Larner traditionelt blevet forstået som en politisk ramme, en ideologi og et styringsparadigme. Neoliberalisme kan forstås både som en politisk diskurs om arten af herskende styringsformer men også som en praksis, der styrer over afstand og som udfolder sig i mikro-processer. Larner fremhæver derfor, at vi skal interessere os for mikro-processer i de konkrete organisationer og indsatser for at få indblik i, hvordan de neoliberale praksisser udfolder sig og virker (Larner, 2000). I Danmark har neoliberalisme - i form af New Public Management - medført en lang række forandringer og tilpasninger. Flere bølger af Moderniseringsprogrammer har igennem en 30-årig periode defineret målsætninger og præstationskriterier for oprindeligt den offentlige sektor men i stigende grad nu også civilsamfundet (Andersen, 2015a). De oprindelige velfærds-moderniseringsprogrammer omfattede service og styrings-innovation (Hartley, 2005), etablering af et kvasi-marked, internt og tvær-institutionelt samarbejde, mere demokrati og personale- og bruger-inddragelse i lokal budgetlægning og aktivitetsprioriteringer. Jeg har påvist, hvordan dette i første omgang førte til intern innovation i social- og sundhedsorganisationerne og først år senere medførte en udvikling af et mere inter-organisatorisk, tværsektorielt og åbent innovationssamarbejde (Andersen, 2015a; Hartley, Sørensen \& Torfing, 2013). Moderniseringsprogrammerne fokuserede også på arbejdspladsindlæring, brug af IT og en mere kvalificeret faglighed, ligesom der var mål for en styrkelse af en multi-aktør læringsstrategi for at skabe et bedre og mere udfoldet samarbejde mellem medarbejdere, ledere og brugere (Andersen, 2015a, s. 252).

Denne udvikling var oprindeligt fokuseret på centrale dele af den offentlige sektor, men har gradvist gjort sig bredt gældende i socialt arbejde og civilsamfundsaktiviteter. For eksempel ser mange civilsamfundsorganisationer sig nødsaget til at søge om offentlige pulje for at finansiere deres aktiviteter, og her stilles krav om formuleringen af en forandringsteori med målbare performance kriterier (Espersen, Andersen, Olsen, \& Tortzen, 2018). Jeg har i min forskning påpeget, hvordan årtiers modernisering af det sociale område har forandret den offentlige sektor og velfærdsindsatser i et betydeligt omfang. En udvikling fra mono-professionelle og interne serviceorganisationer til mere multifaglige og tværgående organisationer; fra konventionelt socialt arbejde eller sygdomsorienteret fokus til en stærkere forebyggende indsats; fra professionelle fagfolk som eneste omsorgspersoner til større grad af samproduktion mellem professionelle, brugere/borgere, styret af 
ngo'er og lokalsamfundet; fra konventionel arbejdsintegration og lokalesamfunds-aktiviteter til flere socialøkonomiske virksomheder og offentlig-private-civile partnerskaber. Disse ændringer har også haft indflydelse på velfærdsprofessionerne og deres personale: fra mono-faglige til plurale og tværfaglige arbejdsfunktioner og kompetencer; fra eneste myndighed til et mere delt, samproduceret og fælles ansvar; og fra at arbejde for udsatte borgere til at arbejde med disse (Andersen, 2015a, s. 257). Forandringerne har forudsat, at de velfærdsprofesionelle har skullet identificere sig fagligt og personligt med de mål, som udgør hjertet i velfærdsindsatserne. Forudsætningen for denne omstilling har været gennemførelsen af et omfattende udviklingsarbejde. Samtidig har jeg også vist, hvordan disse processer, som i dag kendetegner store dele af det offentlige arbejdsmarked, også kan medføre en idealisering, ambivalens og angst, afhængigt af hvordan de er indrammet på de enkelte arbejdspladser - hvad angår organisatoriske, sociale og økonomiske vilkår (Andersen, 2015a, s. 266; Andersen, 2012; Andersen, 1999). I den seneste tid har vi set, hvordan også civilsamfundsorganisationer er begyndt at udvise de samme belastninger og reaktioner, som har kendetegnet offentligt organisationer og arbejdspladser (Rosenberg, 2014; Sievers, 2016; Jørgensen, 2017; Jørgensen og Sievers, 2015).

\section{Civilsamfundsorganisationer: nye arenaer for det ulønnede og lønnede}

Et af civilsamfundets styrker handler om dets evne til at tilbyde arenaer, som har rum for 'tilstedeværelse og at være sammen med' sårbare såvel som almindelige borgere (Andersen, Larsen, Bisballe og Holm, 2008; Andersen, Nerup og Cauchi, 2007). Civilsamfundet rummer også en variation af hverdagsmøder, hvor mange borgere skaber møder og samvær, som har rødder i lokale interesser, men også kan have en bredere horisont. Civilsamfundsorganisationer har typisk været forankret i det, man kan kalde en social rettighedsstrategi, som

"bidrager til at sikre vaerdier som omsorg, pluralisme, samarbejde og bidager med at skabe den nødvendige sociale kapital for velfungerende demokratiske processer "(Sandberg, 2016, s. 55).

Ikke desto mindre er dette gradvis blevet udfordret af det øgede fokus på det entreprenørielle arbejdsmarkedssubjekt, hvor sociale og arbejdsmarkedsindsatser i højere grad nu tegnes i "entreprenørens og ivaerksaetteriets ånd" (Sandberg, 2016). På den danske scene kan vi iagttage dette i udviklingen af nye jobskabende indsatser som for eksempel at give langtidsledige eller hjemløse mikrolån for at kunne etablere mikro-arbejdspladser eller socialøkonomiske virksomheder som ansætter arbejdsløse, kontanthjælpsmodtagere og langtidssyge personer i arbejdsjob, hvor endemål er integration på arbejdsmarkedet. Eller som det illustreres i mit eksempel, hvor udliciteringen af jobintegration til tre CSO'ere - og tilhørende krav - førte til, at borgere på kanten af arbejdsmarkedet skulle gennemføre et forløb med et for ensidigt fokus på entreprenørens markedstræning.

Netop i grænselandet mellem forretning og et frivilligt socialt projekt kan der opstå nogle særlige muligheder for deltagelse for borgere i sårbare positioner. Disse organisationer kan bidrage med at overskride dikotomien mellem at være inden for og uden for arbejdsmarkedet.

"Der etableres her et lønnet arbejdet som er indlejret i en moralsk forpligtelse og ses som en vej mod et medborgerskab igennem indgangen til et 'rigtigt' arbejdsfoellesskab" (Jørgensen \& Sievers, 2015, s. 51). 
Rosenberg har gennemført mikro-analyser af, hvordan dette kan forstås. Heraf fremgår det, at borgere mødes, hvor de er som individer, og at de får stillet en række sociale, oplærende og kvalificerende mulighedsrum til rådighed. Man er ikke nødvendigvis frivillig, jobtilbudsaktiveret eller bruger, men man kan bevæge sig fleksibelt ind og ud af de forskellige positioner. Denne grænseløse struktur i den hybride civilsamfundsorganisationen skaber mulighed for, at brugerne kan være og 'tilblive' på flere forskellige måder i en samtidighed. Og netop dette kan skabe forandringer for borgere i udsatte positioner, fordi det er menneskelig vækst på egne betingelser og i eget tempo (Rosenberg, 2015, s.276ff). Når borgere i jobaktivering arbejder sammen med frivillige aktive om det samme arbejde, udtrykker de stor glæde og stolthed over dette fællesskab, som de beskriver som en skelsættende erfaring. Det ser ud til, at der sker en oplevet subjektiv værditilskrivning, hvor kombinationen af det lønnede og ulønnede rummer et potentiale for at fostre anerkendelse og selvværd hos borgere i udsatte positioner.

Men disse organisationer er samtidig pressede af den selvsamme krise, som de forsøger at afbøde konsekvenserne af. Dette kan føre til effektiviseringer og reduktion i drifts- og omkostningsudgifter og en 'creaming' af deltagerne, hvor de allerdårligste borgere vælges fra.

"Den økonomiske krise virker derfor både stimulerende på alternative virksomhedsformer, men også indskraenkende i forhold til potentielle sproekker der muliggør en udvidelse af arbejdsbegrebet og arbejdspraksisser" (Jørgensen \& Sievers, 2015, s. 50).

Hvorvidt, hybride civilsamfundsorganisationer kan skabe nye rammer for forandring, handling og nye livsudkast for fastlåste unge og voksne, er helt afhængigt af tilstrækkelig tid og ressourcer og fungerende organisationsmodeller. Ofte har disse organisationer en høj ydelseskompleksitet med mange parallelle opgaver og leverancer. Det er et forhold, som er knyttet til det hybride, men er også en udfordring for at sikre bæredygtighed på længere sigt. Forskning viser, at de institutionelle netværk og bæredygtighed - både lokalt og nationalt - er afgørende for deres overlevelse på længere sigt (Andersen, 2015; Andersen \& Hulgård, 2010).

\section{Det ulønnede og de lønnede: om det sociale rettighedssubjekt og det entreprenørielle arbejds- markedssubjekt}

Som et sidste tema vil jeg belyse, hvordan kombinationer af det lønnede og ulønnede i civilsamfundsorganisationer balancerer mellem to forskellige subjekt-positioner, som spidssætter de dilemmaer, som hybride organisationer befinder sig i. Nogle civilsamfundsorganisationer forfølger en indkomst-generering for at understøtte deres sociale mission og de indsatser, de gerne vil gennemføre. Men netop dette dobbelte formål mellem et socialt og et markedsformål rummer en potentiel risiko for, at de må redefinere deres borgere/klienter på måder, som vi kan italesætte som en vareliggørelse. Når borgere/klienter kategoriseres som 'handicappede' eller 'vanskelige at få i arbejde', så kan den arbejds- og social-retlige beskyttelse, som et beskyttet (løn)arbejde på et arbejdsmarked rummer, udtyndes (Garrow \& Hasenfeld, 2014, s. 1484). Dermed kan de hybride virksomheder, som fokuserer på arbejdsintegration, tendere mod at udtynde sociale rettigheder, når og hvis de sætter arbejdsproduktion forrest (Garrow \& Hasenfeld, 2014, s. 1477). Når borgere i jobaktivering i de nye hybride organisationer skal nå de mål, som oftest er eksternt fastsat i de offentlige tilskud, så kan der opstå en modsætning 
mellem den tidsramme og de aktiviteter, som jobaktiveringen tilsiger og den vurdering og de ønsker, som borgeren selv og civilsamfundsorganisationen måtte have.

Betegnelsen om det entreprenørielle arbejdsmarkedssubjekt refererer til den nyere diskurs og praksis, hvor

\section{"nonprofitorganisationer adapterer en tilgang og vaerdier fra det private marked, hvilket kan skade demokrati og statsborgerskab på grund af dens indflydelse på nonprofitorganisatio- ners evne til at skabe og opretholde et stoerkt civilsamfund "(Eikenberry \& Kluver, 2004, s. 132).}

Der er en række forhold, som særligt kendetegner markeds-trenden i nonprofit-sektoren. Det er en kommerciel generering af indtægter, at indgå og få aftaler gennem kontrakt-konkurrence, at nye donor-typer og fonde får stærkere indflydelse. Dette er

\section{LITTERATUR}

Andersen, L. L. (1999). Facader og facetter. Modernisering og loereprocesser $i$ socialpaedagogik og forvaltning. Frederiksberg: Roskilde Universitetsforlag.

Andersen, Linda, L., Larsen, L., Bisballe, L. \& Holm, L. (2008). Kommunernes samarbejde med de frivillige sociale foreninger. En casebaseret analyse. København: Velfærdsministeriet.

Andersen, L. L., Nerup, S. \& Cauchi, P. (2007). Paragraf 18. En casebaseret analyse af samarbejdet mellem kommunerne og de frivillige sociale foreninger. København: Socialministeriet, Frivilligenheden.

Andersen, L. L. (2012). Læringsarenaer i menneskearbejdet. Forførende retorik, ambivalente aktører og neoliberal nøjsomhed. Social Kritik, 131, 42-57.

Andersen, L. L. (2015a). Micro-processes of collaborative innovation in Danish welfare settings: a psychosocial approach to learning tilstande som i varierende grader kendetegner dele af civilsamfundet i Danmark. Når en markedsorientering bliver stærkere, så følger det heraf, at en entreprenøriel tilgang har en stor betydning for, om markedsstrategien bliver en succes. Og at formidlingen af iværksætteri og iværksætteråndens diskurser bliver afgørende sigtepunkter for ikke bare markedet i private virksomheder, men nu også for den offentlige sektor og for dele af civilsamfundet (Sandberg, 2016). Som en modpol er den rettighedsbaserede tilgang rodfæstet i en særlig forståelse, hvor moderne velfærdsstater er bygget på og af subjekter eller borgere, der bør beskyttes i økonomiske, politiske og sociale sammenhænge af en velfærdsstat, som garanterer de individuelle rettigheder (Boje, 2015, s. 30). Her ser vi altså konturerne af de to positioner, som i denne tid både virker sammen og kolliderer i en række sociale og arbejdsmarkeds-aktiviteter og indsatser.

and performance. Collaborative Governance and Public Innovation in Northern Europe (pp. 249-268): Bentham EBooks,.

Andersen, L.L. (2015b). Social Entrepreneurship and Social Innovation: Human Economy, Governance and Volunteerism Revisited. Cursiv, (15), 35-54.

Andersen, L. L., (2005). The long gone promise of social work: Ambivalence and individualisation in social services administration. Journal of Social Work Practice, 19(1), 73-86.

Andersen, L. L. \& Espersen, H. H. (2017). Samskabelse, samproduktion og partnerskaber - teoretiske perspektiver [Co-creation, co-production and partnerships: theoretical perspectives]. In Partnerskaber og samarbejder mellem det offentlige og civilsamfundet (pp. 107-137). København: Socialstyrelsen. 
Andersen, L. L., Gawell, M. \& Spear, R. (2016). Social Entrepreneurship and Social Enterprises: Nordic Perspectives. London: Routledge.

Andersen, L. L. \& Hulgård, L. (2016). Social Entrepreneurship: Demolition of the Welfare State or an Arena for Solidarity? In L. L. Andersen, M. Gawell \& R. Spear (eds.), Social Entrepreneurship and Social Enterprises: Nordic Perspectives (pp. 22-40). London: Routledge.

Andersen, L. L. \& Hulgård, L. (2010). Social entreprenørskab - fyrtårne og kuldsejlede projekter. In L. Andersen, Linda, T. Bager \& L. Hulgård (eds.), Socialt entreprenørskab (pp. 169-177). Odense: Odense Universitetsforlag.

Billis, D. (2010). Towards a theory of hybrid organizations. In D. Billis (ed.), Hybrid Organizations and the Third Sector (pp. 46-69). Basingstoke, Hampshire, UK: Palgrave Macmillan.Boje, T. P. (2015). Citizenship, Democratic Participation, and Civil Society. Cursiv, (15), 27-45.

Boje, T. P. (2017). Civilsamfund, medborgerskab og deltagelse. Copenhagen: Hans Reitzels Forlag. Brandsen, T., van de Donk, W. \& Putters, K. (2005). Griffins or Chameleons? Hybridity as a Permanent and Inevitable Characteristic of the Third Sector. International Journal of Public Administration, 28(9-10),749-765. Available at: http://www.tandfonline.com/ doi/abs/10.1081/PAD-200067320.

Buckingham, H. (2011). Hybridity, diversity and the division of labour in the third sector: what can we learn from homelessness organisations in the UK? Voluntary Sector Review, 2(2), 157-175

Enjolras, B. \& Strømsnes, K. (2017). Scandinavian Civil Society and Social Transformations: The Case of Norway. In B. Enroljas \& K. Strømsnes (eds.), London: Springer.

Espersen, H. H., Andersen, L. L., Olsen, L., \& Tortzen, A. (2018). Understøttelse og udvikling af det frivillige sociale arbejde. En analyse af udviklingstendenser og behov for kontinuitet og forandring $i$ nationale virkemidler. Copenhagen: VIVE

Evers, A. (2005). Mixed Welfare Systems and Hybrid Organizations: Changes in the Governance and Provision of Social Services. International Journal of Public Administration, 28, 737-748.
Fridberg, T., \& Henriksen Skov, L. (2014). Udviklingen i frivilligt arbejde 2004-2012. København: SFI 14:09. Retrieved from https://pisa2012.dk/ Files/Filer/SFI/Pdf/Rapporter/2014/1409-Udviklingen-i-frivilligt-arbejde.pdf

Garrow, E. E. \& Hasenfeld, Y. (2014). Social Enterprises as an Embodiment of a Neoliberal Welfare Logic. American Behavioral Scientist, 58(11), 1475-1493.

Hartley, J. (2005). Innovation in Governance and Public Services: Past and Present. Public Money \& Management, 25(1), 27-34.

Hartley, J., Sørensen, E. \& Torfing, J. (2013). Collaborative innovation: A viable alternative to market competition and organizational entrepreneurship. Public Administration Review, 73(6), 821-830.

Henriksen, L. S., Boje, T. P \& Ibsen, B. (2008). Welfare architecture and voluntarism. The Third Sector in Europe: Prospects and Challenges, 8, 69. Jørgensen, R. E. (2017). "Vi er altid faldet mellem flere stole". Socialøkonomi og social virksomhed "betwixt and between." Phd afhandling. Roskilde Universitet.

Jørgensen, R. E. \& Sievers, S. M. M. (2015). Mellem arbejde og "off-day" - tvetydighedens muligheder i sociale virksomheder. Tidsskrift for Arbejdsliv, 17(3), 48-62.

La Cour, A., \& Højlund, H. (2008). Voluntary social work as a paradox. Acta Sociologica, 51(1), 41-54. https://doi.org/10.1177/0001699307086817

Larner, W. (2000). Neo-liberalism: Policy, Ideology, Governmentality. Studies in Political Economy, 63, 5-25.

Mair, J., Mayer, J. \& Lutz, E. (2015). Navigating Institutional Plurality: Organizational Governance in Hybrid Organizations. Organization Studies, 36(6), 713-739.

Mair, J. \& Noboa, E. (2003). The Emergence of Social Enterprises and their Place in the New Organizational Landscape. IESE Working Paper No. D/523, 3(523).

Mason, C. (2012). Isomorphism, Social Enterprise and the Pressure to Maximise Social Benefit. Journal of Social Entrepreneurship, 3(1), 74-95.

Pestoff, V. (2014). Hybridity, Coproduction, and Third Sector Social Services in Europe. American Behavioral Scientist, 58(11), 1412-1424. 
Rosenberg, C. (2014). SydhavnsCompagniet. Tilblivelser, relationer og muligheder i stribede og glatte rum. Roskilde University.

Sandberg, B. (2016). Against the Cult(ure) of the Entrepreneur for the Nonprofit Sector. Administrative Theory \& Praxis, 38(1), 52-67. Available at: http://www.tandfonline.com/doi/full/10. 1080/10841806.2015.1130524.

Sievers, S. M. M. (2016). Social innovation i civilsamfundet: kætteri og flertydigheder i arbejdet med socialt udsatte. Phd afhandling, Roskilde Universitet.
Wijkström, F. (2011). "Charity Speak and Business Talk". The On-Going (Re)hybridization of Civil Society. In A. Wijkström, F. Zimmer (eds.), Nordic Civil Society at a Cross-Roads. Transforming the Popular Movement Tradition (pp. 27-55). Baden-Baden: Nomos Verlagsgesellschaft.

Wijkström, F. \& Zimmer, A. (2011). Introduction: Nordic Civil Societies beyond Membership and Movements. In F. Wijkström \& A. Zimmer (eds.), Baden-Baden: Nomos Verlagsgesellschaft.

Linda Lundgaard Andersen, professor, ph.d.

Institut for Mennesker og Teknologi, Roskilde Universitet e-mail:1la@ruc.dk 